\title{
Towards scalable production of a collagen-like protein from Streptococcus pyogenes for biomedical applications
}

Yong Y Peng, Linda Howell, Violet Stoichevska, Jerome A Werkmeister, Geoff J Dumsday and John A M Ramshaw*

\begin{abstract}
Background: Collagen has proved valuable as biomedical materials for a range of clinical applications, particularly in wound healing. It is normally produced from animal sources, such as from bovines, but concerns have emerged over transmission of diseases. Recombinant collagens would be preferable, but are difficult to produce. Recently, studies have shown that 'collagens' from bacteria, including Streptococcus pyogenes, can be produced in the laboratory as recombinant products, and that these are biocompatible. In the present study we have established that examples of bacterial collagens can be produced in a bioreactor with high yields providing proof of manufacture of this important group of proteins.
\end{abstract}

Results: Production trials in shake flask cultures gave low yields of recombinant product, $<1 \mathrm{~g} / \mathrm{L}$. Increased yields, of around $1 \mathrm{~g} / \mathrm{L}$, were obtained when the shake flask process was transferred to a stirred tank bioreactor, and the yield was further enhanced to around $10 \mathrm{~g} / \mathrm{L}$ by implementation of a high cell density fed-batch process and the use of suitably formulated fully defined media. Similar yields were obtained with 2 different constructs, one containing an introduced heparin binding domain. The best yields, of up to $19 \mathrm{~g} / \mathrm{L}$ were obtained using this high cell density strategy, with an extended $24 \mathrm{~h}$ production time.

Conclusions: These data have shown that recombinant bacterial collagen from S. pyogenes, can be produced in sufficient yield by a scalable microbial production process to give commercially acceptable yields for broad use in biomedical applications.

Keywords: Bacterial collagen, Recombinant protein production, Bioreactor, High cell density, pCold vector, Defined medium, Fed-batch process

\section{Background}

Collagens are the major structural proteins in the extracellular matrix of animals, including all vertebrates and invertebrates $[1,2]$. Collagens are defined by a characteristic triple-helix structure in which 3 polyproline-II-like helices are super-coiled around a common axis to give a rope-like structure [3]. In this structure, the only amino acid that is small enough to fit within the centre of the triple-helix is glycine (Gly), leading to a characteristic, repeating amino acid sequence for the collagen triplehelix of (Gly-Xaa-Yaa) $)_{n}$, where Xaa and Yaa can be any amino acid, but are frequently proline (Pro) as Xaa and

* Correspondence: John.Ramshaw@csiro.au Australia

\section{() Biomed Central}

4-hydroxyproline (Hyp) as Yaa [3]. Only a limited number of Gly-Xaa-Yaa triplet sequences are found in high frequency, while over one third of all possible triplets have not been observed in natural sequences [4]. Those that occur in higher frequency are often associated with sequences that enhance the stability of the triple helix, and include segments where hydrophobic residues or charged pair interactions are present, as well as Hyp containing sequences [5].

Collagen has been proven safe and effective in a wide variety of medical products and in various clinical applications [6,7]. For medical purposes, collagen is usually extracted from animal sources, especially bovine, but there has been a growing concern of transmissible diseases arising from use of this source. The ready availability of a cost effective recombinant collagen would, 
therefore, be a clear advantage. Progress has been made in developing the commercial production of human recombinant collagens in yeasts [8-11], with yields of around $2 \mathrm{~g} / \mathrm{L}$ being achieved in Pichia pastoris [12]. However, this system requires the co-expression of the enzyme prolyl 4-hydroxylase $(\mathrm{P} 4 \mathrm{H})$ which leads to secondary modification of certain Pro residues to give Нyp that contributes to collagen stability. This, in turn, requires additional oxygenation during the fermentation process to facilitate hydroxylation as well as the addition of methanol for induction, adding to the complexity and cost of production [12]. Previously, the incorporation of Hyp in Escherichia coli cultures had been proposed, through incorporation of Hyp in the media [13], but this leads to non-specific incorporation into both the Xaa and Yaa positions in the triple helix. More recently, specific incorporation of Hyp into the Yaa position in E. coli cultures, but for only small collagen peptides, has been reported using a biosynthetic shunt to produce ascorbatelike entities that drive heterologously expressed $\mathrm{P} 4 \mathrm{H}$ [14].

Collagen-like triple-helical sequences with Gly at every third residue and a high Pro content have been observed in various bacteria [15-17]. These bacterial collagen-like proteins lack prolyl hydroxylation, yet several have been shown to form stable triple-helices at $35-38^{\circ} \mathrm{C}$ [17], through use of alternative stabilisation motifs [18]. These collagen proteins can, therefore, be expressed as recombinant products in an $E$. coli system without the need for $\mathrm{P} 4 \mathrm{H}$ co-expression $[15,18]$.

The bacterial collagen examined in this present study, with its limited biological interactions behaves like a 'blank slate', which could be used in clinical applications such as wound management or adhesion prevention. It can be modified to include additional copies of the collagen domain [19] or by inclusion of other mammalian collagen sequences [20] or other triple helical proteins. For example, it is possible to introduce specific functions, such as cell binding via a mammalian integrin binding site [21,22] or inclusion of a heparin binding domain $[23,24]$ into the bacterial collagen domain.

In this study we have produced the recombinant collagen-like protein Scl2 from S. pyogenes in E. coli using a stirred tank bioreactor. The $\mathrm{Scl} 2$ sequence, including the registration domain (V-domain), the collagen domain $(\mathrm{CL})$, but without the $\mathrm{C}$-terminal non-collagen tail, was inserted into a pColdIII (Takara Bio Inc.) vector for expression in E. coli [18]. As an example of this new class of collagens, the recombinant $\mathrm{Scl} 2$ gene construct from $S$. pyogenes has previously been expressed in shake flasks $[18,25]$. The purified collagen protein was shown to be non-cytotoxic and non-immunogenic, while supporting cell attachment, although cell spreading was limited at $16 \mathrm{~h} \mathrm{[25].}$

If this bacterial collagen or its modified sequences are to be used as new clinical materials, it is important that they can be produced in commercially feasible quantities at a competitive cost for biomedical product manufacture. This study has established that this collagen can be produced in good yield in a bioreactor using a cost effective fully defined medium.

\section{Results and discussion}

Protein expression constructs

In the present study, recombinant bacterial collagen, VCL, has been expressed using the pCold vector system, as it had previously been shown that this system was effective in shaker culture for production of the protein in the $E$.coli host strain BL21 [18,25]. The construct was termed VCL, where $\mathrm{V}$ is the non-triple-helical registration domain and $\mathrm{CL}$ is the triple-helical, collagen-like domain (Figure 1). The pCold vectors selectively induce target protein synthesis at low temperatures where the synthesis of host proteins is reduced or suppressed and protease activity is decreased. The pCold system is designed for efficient protein expression utilising a promoter derived from the $\operatorname{csp} A$ gene, which is a cold-shock gene, with a lac operator inserted downstream to control expression [26]. In addition, expression of a second construct, VCLH, which included a heparin binding domain, $H$, substituted using site directed mutagenesis into the CL sequence, was also tested. In this construct, a heparin binding sequence, GRPGKRGKQGQK, derived from the collagenous tail of acetylcholine esterase [23,24] was substituted via PCR directed integration into the CL sequence GPAGPMGPAGER that starts at base pair 564/amino acid residue 188 (Figure 1). The substitution was confirmed by DNA sequencing. The pCold vector system is available as a research tool; it is possible that proprietary commercial vectors could give much better yields than observed in the present study that has used the pCold system. Recombinant proteins, VCL and VCLH, were isolated in sufficient quantities for use as electrophoretic quantitation standards (Figure 2A) using a conventional purification protocol (Ni metal affinity column chromatography and with binding via a $\mathrm{His}_{6}$ tag incorporated at the N-terminus of the protein). Final purification was achieved by gel permeation chromatography [25].

\section{Protein expression in shake flasks}

The expression of VCL in shake flasks using $2 \mathrm{xYT}$ Media and Defined Media (DM) were used as the baseline process for this study. Cells were grown for $24 \mathrm{~h}$ at $37^{\circ} \mathrm{C}$, after which an $\mathrm{OD}_{600 \mathrm{~nm}}$ of around 6 was achieved, prior to induction at $25^{\circ} \mathrm{C}$. Expressed protein production was determined after incubation at $25^{\circ} \mathrm{C}$ for $10 \mathrm{~h}$, followed by a further $14 \mathrm{~h}$ at $15^{\circ} \mathrm{C}$. It was hoped that the additional reduction in temperature would maintain the selective target protein production achieved by the pCold vector system. The changes in cell densities were 

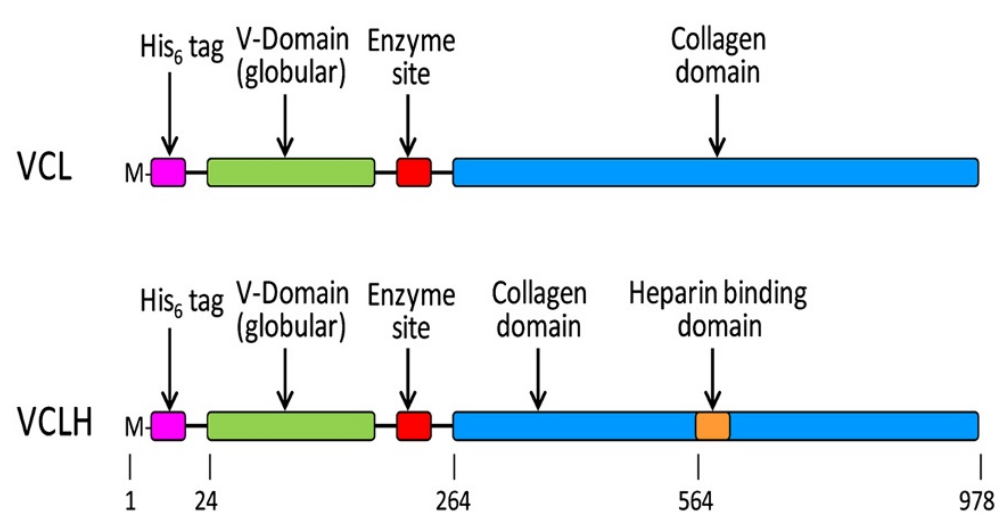

Figure 1 Schematic diagrams showing the VCL and VCLH constructs. Base pair numbers are indicated below the schematics. The His-Tag and Enzyme Site domains have been added to the naturally occurring S. pyogenes Scl2.28 gene [15] as previously described [25].

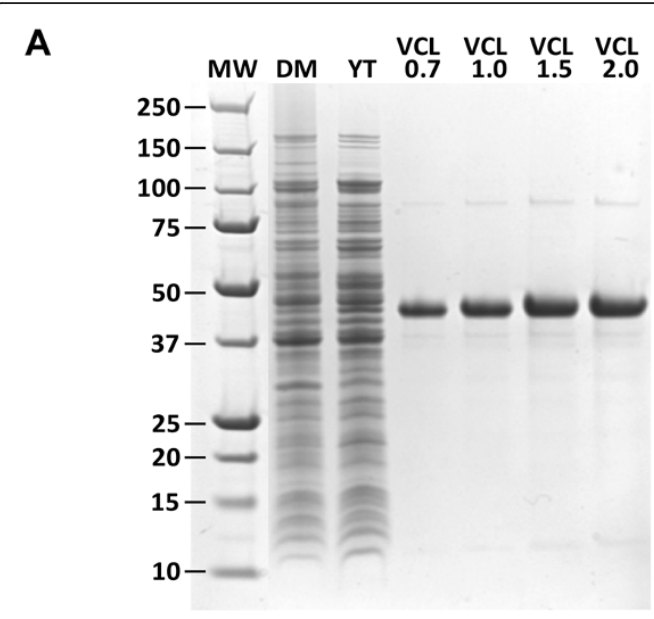

$\mathbf{B}$

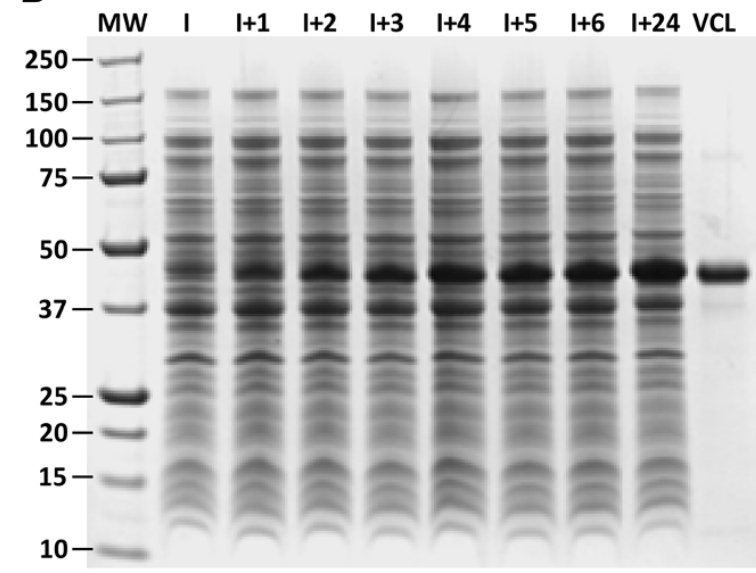

Figure 2 SDS-PAGE analysis of protein expression. (A) Protein expression in shake flask cultures. MW, molecular weight standards; DM, defined medium; YT, complex medium (2xYT) and purified VCL protein standards 0.7 to $2.0 \mathrm{\mu g}$. (B) Protein expression time course, fed-batch process with stepwise temperature reduction after induction. MW, molecular weight standards; I, pre-induction; I + 1 to I + 24 hours after induction; VCL, purified VCL standard. tracked throughout the process (Figure 3A), and at the end of the production phase, moderate amounts of wet cell paste, $8.3 \mathrm{~g} / \mathrm{L}$ for $\mathrm{DM}$ and $9.7 \mathrm{~g} / \mathrm{L}$ for $2 \mathrm{xYT}$, were obtained. Expression yields were determined by comparison to known amounts of VCL protein by SDSPAGE (Figure 2A). These shake flask processes achieved recombinant collagen expression levels of around $0.2 \mathrm{~g} / \mathrm{L}$ in DM and $0.3 \mathrm{~g} / \mathrm{L}$ in $2 x Y T$ (Table 1 ). These yields are adequate for biochemical and biophysical studies of VCL and related constructs such as VCLH, but are well below production levels required for commercial production.

\section{Protein expression in $2 \mathrm{~L}$ stirred tanks - batch process (low cell density)}

Expression of both the VCL and the VCLH was tested using a batch process in a $2 \mathrm{~L}$ stirred tank bioreactor. After inoculation, both processes were maintained at $37^{\circ} \mathrm{C}$ for the first 5 hours to increase the cell density prior to induction. After this initial period, the culture had an optical density $\mathrm{OD}_{600 \mathrm{~nm}}$ in the range of 2 to 3 . The cultures were then cooled to $25^{\circ} \mathrm{C}$, induced with IPTG and incubated for a further $7 \mathrm{~h}$. For both constructs, wet cell paste yields were between 5 and $6 \mathrm{~g} / \mathrm{L}$. The increase in cell density was tracked throughout (Figure 3A), showing, steady increases in both cases. The final optical densities were below those achieved in shake flasks reflecting the shorter times for both the growth and induction phases in the bioreactor experiments. Despite the shorter incubation times, both trials led to moderate recombinant collagen yields, 0.7 to $1.0 \mathrm{~g} / \mathrm{L}$. Transfer of the process to a more controlled bioreactor resulted in a 3-fold increase in total collagen production and a 4-fold increase in specific productivity (mass of collagen per cell), although further yield increases are required to meet the requirements of commercial production. 


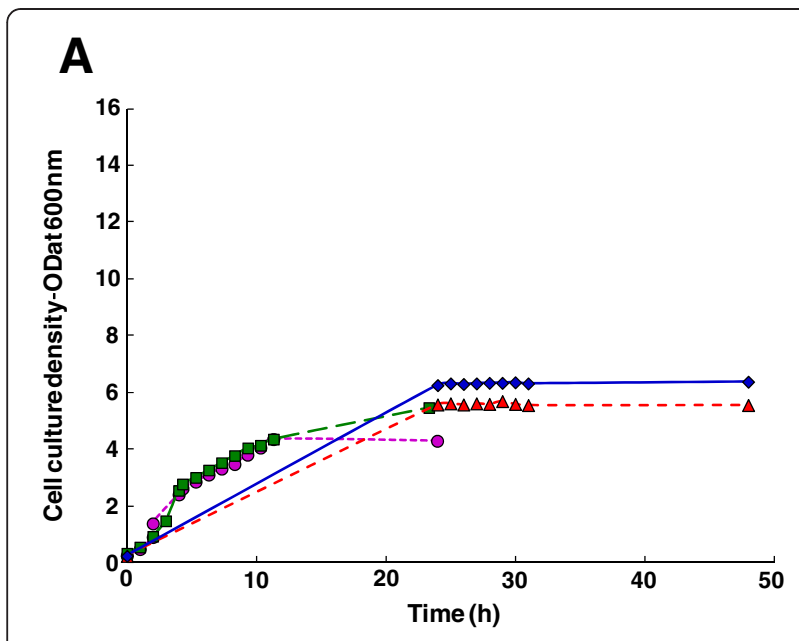

B

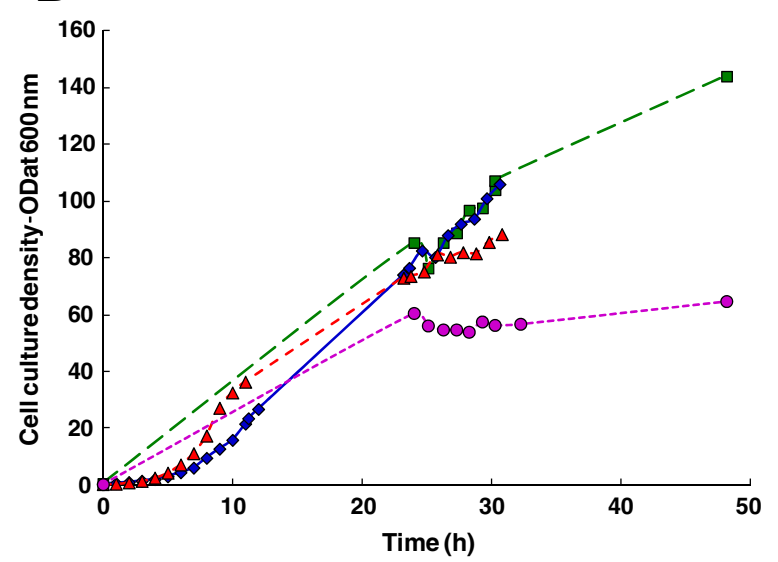

Figure 3 Effect of fermentation process design and induction temperature on growth of collagen-producing $E$. coli strains. Cell concentration was estimated by measuring optical density at $600 \mathrm{~nm}$. See Table 1 for experimental details. (A) Shake flask and low cell density processes $\$$ VCL, shake flask, complex medium $(2 \times Y T) ; \boldsymbol{\Lambda}, V C L$, shake flask, defined medium; $\mathbf{m}, \mathrm{VCL}$, bioreactor batch process (low cell density); $\bullet$, VCLH, bioreactor batch process (low cell density). (B) High cell density processes. $\downarrow$, VCLH, bioreactor fed-batch process, induction at $25^{\circ} \mathrm{C}$ for 10 hours; $\mathbf{\Delta}, \mathrm{VCL}$, bioreactor fed-batch process, induction at $25^{\circ} \mathrm{C}$ for 10 hours; $\bullet$, VCL, bioreactor fed-batch process, induction at $15^{\circ} \mathrm{C}$ for 24 hours; $\mathbf{\square}, \mathrm{VCL}$, bioreactor fed-batch process, induction for 24 hours with stepwise temperature reduction.

\section{Protein expression in $\mathbf{2 L}$ stirred tanks - fed-batch process (high cell density)}

Both the VCL and VCLH constructs were used for initial testing of expression using a high cell density, fed-batch process. A high cell density process was implemented to increase collagen production. If the specific collagen productivity (mass of collagen per cell) can be maintained then an increase in cell density will result in an increase in collagen production. To achieve a high cell density prior to induction, the initial growth phase was extended to $24 \mathrm{~h}$ during which cell densities typically exceeding $\mathrm{OD}_{600} \mathrm{~nm}$ of 80 were obtained. Again, the temperature was reduced to $25^{\circ} \mathrm{C}$ and recombinant protein expression induced by the addition of IPTG; the culture was incubated for a further $10 \mathrm{~h}$. The process resulted in a significant improvement in collagen yields; $8.2 \mathrm{~g} / \mathrm{L}$ for $\mathrm{VCLH}$ and $9.5 \mathrm{~g} / \mathrm{L}$ for VCL, indicating that this fermentation approach has potential for high level production of the recombinant protein. The specific productivity was less compared to the low cell density process but due to the large increase in cell mass the volumetric productivity increased almost 10-fold. As the differences between VCL and VCLH production were relatively small, only VCL was used for further process optimisation.

The previous experiment showed that a $12^{\circ} \mathrm{C}$ temperature decrease resulted in collagen yields in excess of $8 \mathrm{~g} / \mathrm{L}$. The effect of induction temperature was examined further by following a similar protocol, except the induction was changed from $25^{\circ} \mathrm{C}$ to $15^{\circ} \mathrm{C}$ and the induction time was increased from 10 to $24 \mathrm{~h}$. This process was used to test whether a lower temperature would further reduce host cell protein production resulting in greater enrichment of recombinant collagen. The lower induction temperature did result in greater enrichment of the target protein (the specific productivity increased 2-fold) whilst volumetric production was similar to the previous experiment $(9.5 \mathrm{~g} / \mathrm{L}$ at $25^{\circ} \mathrm{C}$ and $10 \mathrm{~g} / \mathrm{L}$ at $15^{\circ} \mathrm{C}$ ). The final optical density was lower at $15^{\circ} \mathrm{C}\left(\mathrm{OD}_{600} \mathrm{~nm}=65\right)$ compared to $25^{\circ} \mathrm{C}$ $\left(\mathrm{OD}_{600} \mathrm{~nm}=88\right)$ despite the induction time being increased from 10 to 24 hours. The unchanged volumetric production was most likely the result of slower cell growth at the lower temperature as shown in Figure 3B; cell growth is negligible after reducing the temperature to $15^{\circ} \mathrm{C}$.

To further increase recombinant collagen production the extended induction time was retained and stepwise temperature reduction was introduced into the process to enhance pCold's "cold shock selectivity". After induction for $10 \mathrm{~h}$ at $25^{\circ} \mathrm{C}$, the temperature was reduced to $20^{\circ} \mathrm{C}$ and the culture held at this temperature for $5 \mathrm{~h}$. The temperature was then reduced again to $15^{\circ} \mathrm{C}$ and held at this temperature for a further $9 \mathrm{~h}$. This process change resulted in a further marked yield increase with recombinant collagen production levels of 13.0, 19.0 and $19.3 \mathrm{~g} / \mathrm{L}$ in three separate batches (average of $17.1 \mathrm{~g} / \mathrm{L}$ ) production levels that are potentially within a commercially feasible range. The stepwise temperature reduction resulted in an increase in final optical density without too greater impact on specific productivity. Recombinant collagen production was followed during the induction phase of the process using SDS-PAGE (Figure 2B) which shows a steady increase in VCL production during the initial hours after induction with a further increase at the end of 
Table 1 Fermentation conditions and protein yields for VCL and VCLH constructs

\begin{tabular}{|c|c|c|c|c|c|c|c|c|}
\hline Construct & Process & $\begin{array}{c}\text { Pre- } \\
\text { induction phase }\end{array}$ & $\begin{array}{c}\text { Induction } \\
\text { temperature }\left({ }^{\circ} \mathrm{C}\right)\end{array}$ & $\begin{array}{l}\text { Induction } \\
\text { phase }\end{array}$ & $\begin{array}{l}\text { Final OD } \\
(600 \mathrm{~nm})\end{array}$ & $\begin{array}{c}\text { Wet cell } \\
\text { paste }(g / L)\end{array}$ & $\begin{array}{l}\text { Volumetric } \\
\text { productivity } \\
(\mathrm{g} / \mathrm{L})\end{array}$ & $\begin{array}{l}\text { Specific } \\
\text { productivity } \\
\left(\mathrm{g} / \mathrm{OD}_{600 \mathrm{~nm}}\right)\end{array}$ \\
\hline VCL & $\begin{array}{l}\text { Flask Complex } \\
\text { medium }\end{array}$ & $24 \mathrm{~h}$ at $37^{\circ} \mathrm{C}$ & 25 & $\begin{array}{c}25^{\circ} \mathrm{C} \text { for } 10 \mathrm{~h} 15^{\circ} \mathrm{C} \text { for } \\
14 \mathrm{~h}\end{array}$ & 6.4 & 9.7 & 0.3 & 0.05 \\
\hline VCL & $\begin{array}{l}\text { Flask Defined } \\
\text { medium }\end{array}$ & $24 \mathrm{~h}$ at $37^{\circ} \mathrm{C}$ & 25 & $\begin{array}{c}25^{\circ} \mathrm{C} \text { for } 10 \mathrm{~h} 15^{\circ} \mathrm{C} \text { for } \\
14 \mathrm{~h}\end{array}$ & 5.6 & 8.3 & 0.2 & 0.04 \\
\hline VCL & $\begin{array}{l}\text { Batch Defined } \\
\text { medium }\end{array}$ & $5 \mathrm{~h}$ at $37^{\circ} \mathrm{C}$ & 25 & $25^{\circ} \mathrm{C}$ for $7 \mathrm{~h}$ & 5.5 & 5.3 & 0.7 & 0.13 \\
\hline VCLH & $\begin{array}{l}\text { Batch Defined } \\
\text { medium }\end{array}$ & $5 \mathrm{~h}$ at $37^{\circ} \mathrm{C}$ & 25 & $25^{\circ} \mathrm{C}$ for $7 \mathrm{~h}$ & 4.3 & 5.8 & 1.0 & 0.23 \\
\hline \multirow[t]{2}{*}{ VCLH } & $\begin{array}{l}\text { Fed batch } \\
\text { Defined } \\
\text { medium }\end{array}$ & $24 \mathrm{~h}$ at $37^{\circ} \mathrm{C}$ & 25 & $25^{\circ} \mathrm{C}$ for $10 \mathrm{~h}$ & 106 & 108 & 8.2 & 0.08 \\
\hline & $\begin{array}{l}\text { Fed batch } \\
\text { Defined } \\
\text { medium }\end{array}$ & $24 \mathrm{~h}$ at $37^{\circ} \mathrm{C}$ & 25 & $25^{\circ} \mathrm{C}$ for $10 \mathrm{~h}$ & 88 & 113 & 9.5 & 0.11 \\
\hline VCL & $\begin{array}{l}\text { Fed batch } \\
\text { Defined } \\
\text { medium }\end{array}$ & $24 \mathrm{~h}$ at $37^{\circ} \mathrm{C}$ & 15 & $15^{\circ} \mathrm{C}$ for $24 \mathrm{~h}$ & 65 & 112 & 10.0 & 0.15 \\
\hline VCL & $\begin{array}{l}\text { Fed batch } \\
\text { Defined } \\
\text { medium }\end{array}$ & $24 \mathrm{~h}$ at $37^{\circ} \mathrm{C}$ & 25 & $\begin{array}{l}25^{\circ} \mathrm{C} \text { for } 10 \mathrm{~h} 20^{\circ} \mathrm{C} \text { for } \\
5 \mathrm{~h} 15^{\circ} \mathrm{C} \text { for } 9 \mathrm{~h}\end{array}$ & 96 & n.d. & 19.3 & 0.20 \\
\hline VCL & $\begin{array}{l}\text { Fed batch } \\
\text { Defined } \\
\text { medium }\end{array}$ & $24 \mathrm{~h}$ at $37^{\circ} \mathrm{C}$ & 25 & $\begin{array}{c}25^{\circ} \mathrm{C} \text { for } 10 \mathrm{~h} 20^{\circ} \mathrm{C} \text { for } \\
5 \mathrm{~h} 15^{\circ} \mathrm{C} \text { for } 9 \mathrm{~h}\end{array}$ & 105 & 137 & 13.0 & 0.12 \\
\hline VCL & $\begin{array}{l}\text { Fed batch } \\
\text { Defined } \\
\text { medium }\end{array}$ & $24 \mathrm{~h}$ at $37^{\circ} \mathrm{C}$ & 25 & $\begin{array}{c}25^{\circ} \mathrm{C} \text { for } 10 \mathrm{~h} 20^{\circ} \mathrm{C} \text { for } \\
5 \mathrm{~h} 15^{\circ} \mathrm{C} \text { for } 9 \mathrm{~h}\end{array}$ & 144 & 148 & 19.0 & 0.13 \\
\hline
\end{tabular}

the process. In addition, purified protein samples from cell aliquots, for use as gel standards, also showed that the collagen domains of the expressed products were resistant to trypsin digestion [19] indicating that the collagen domains had folded into the triple-helical conformation which confers proteolytic resistance [19].

In the present study, we have shown that good production levels of VCL can be achieved, with a maximum production of $19.3 \mathrm{~g} / \mathrm{L}$. After removal of the $\mathrm{His}_{6}$ tag and the V-domain, which would probably be necessary for biomedical applications of the collagen-like domain, this equates to a maximum yield of the CL domain of about $14.1 \mathrm{~g} / \mathrm{L}$, with a further loss of yield depending on the efficiency of any purification protocol. The use of the $\mathrm{His}_{6}$ tag is efficient for laboratory purifications $[19,25]$, but would not be suitable for large scale commercial preparations. Other affinity approaches may be more useful and cost effective, including the use of specific collagen binding proteins [27]. The present study has shown that excellent recombinant collagen yields can be obtained using a high cell density fed-batch process using pCold vectors. The best yields obtained compare favourably with the average yields reported for other bacterial expression studies of $14 \mathrm{~g} / \mathrm{L}$ [28], although there may be higher commercial yields that remain commercial-in- confidence. Nevertheless, use of alternative vector systems that may be better suited for use at high cell densities may lead to even further increases in yield. The present yield, however, compares favourably with fedbatch fermentation yields obtained using $P$. pastoris and Hansenula polymorpha. These recombinant systems were used to produce a $30 \mathrm{kDa}$ fragment containing an $\mathrm{N}$-propeptide which after cleavage gives a $14 \mathrm{kDa}$ mammalian collagen fragment in the yeasts $P$. pastoris and Hansenula polymorpha (recently designated as a Pichia species) [10]. These data gave the best yield with $H$. polymorpha expression of around $0.6 \mathrm{~g} / \mathrm{L}$, well below the bacterial collagen yields achieved in this study. Nevertheless, much better yields, better than $2 \mathrm{~g} / \mathrm{L}$, could be obtained from $P$. pastoris when used in commercially optimised production [12].

\section{Conclusions}

An initial optimisation approach of the present pCold vector system showed that recombinant bacterial collagen can be produced in large quantities in E. coli, with average production levels of $17.1 \mathrm{~g} / \mathrm{L}$, much greater than has been achieved for mammalian collagens in yeast expression systems [12]. This was achieved at low cost through use of a fully defined medium, which was 
formulated without any animal products, and without the introduction of any media components that could have a negative impact on downstream processing. The bacterial production system was not affected by the introduction of a heparin binding sequence, with comparable yields being obtained for both the VCL and VCLH constructs.

Bacterial collagen is an excellent alternative source of collagen for use in biomaterial applications and as a scaffold for tissue engineering. As a bacterially expressed product, it can be made as a non-animal collagen in an animal free system. As an expressed product, it does not have the variation in quality, purity and predictability of performance that can be found for animal derived materials, nor does it carry the risk of transmission of infectious agents. The properties of the bacterial collagen from S. pyogenes have been characterised [25]. It has been shown that this bacterial collagen is biocompatible, non-cytotoxic and non-immunogenic [25] and hence suitable for biomaterial applications. This collagen is stable without the need for secondary modifications, especially proline hydroxylation. The bacterial collagen system also allows for the design of novel functional materials, such as the inclusion of selected binding domains, eg: introducing integrin binding domains [22] or heparin binding into the natural bacterial collagen sequence.

\section{Methods}

\section{Recombinant construct}

The fragment of S. pyogenes Scl2.28 gene [15] encoding the globular (V) and the collagen-like (CL) domains, and the variations to include a His-tag at the N-terminal of the $\mathrm{V}$-domain and an enzyme cleavage site between the Vand $\mathrm{CL}$ domains, was cloned into the pColdIII vector (Takara Bio, Shiga, Japan), giving construct VCL, and transformed for expression in E. coli strain BL21 as previously described [25]. In addition, the construct was cloned into the shuttle vector pSL1180 using restriction sites $5^{\prime}$ NdeI and $3^{\prime}$ BamHI. This clone was used for site directed mutagenesis to introduce a heparin binding sequence [23,24] GRPGKRGKQGQK at base pair 564 via PCR directed integration, giving construct VCLH. PCR products were treated with DpnI, to digest all parental DNA and subsequently transformed into E. coli strain XL1-BLUE. Selected DNA clones were sequenced and those containing the required heparin binding domain was subcloned into pColdIII vector (Takara Bio, Shiga, Japan) using the $5^{\prime} \mathrm{NdeI}$ and $3^{\prime}$ BamHI sites. Positive clones were selected and transformed into E. coli host BL21 for expression. Schematics of the two constructs are shown in Figure 1. Prior to expression studies, all constructs were confirmed by DNA sequencing.

\section{Media}

Complex medium (2xYT) contained $16 \mathrm{~g}$ tryptone, $10 \mathrm{~g}$ yeast extract and $5 \mathrm{~g} \mathrm{NaCl}$ per litre. The defined medium (DM) used in this study contained per litre: $\mathrm{KH}_{2} \mathrm{PO}_{4}, 10.6$ g; $\left(\mathrm{NH}_{4}\right)_{2} \mathrm{HPO}_{4}, 4.0$ g; citric acid, 1.7 g; glucose, $25 \mathrm{~g}$; $\mathrm{MgSO}_{4} .7 \mathrm{H}_{2} \mathrm{O}, 1.23 \mathrm{~g}$; ampicillin, $200 \mathrm{mg}$; thiamine hydrochloride, $4.4 \mathrm{mg}$; and trace salts solution $5 \mathrm{~mL}$. The trace salts solution contained per litre: $\mathrm{CuSO}_{4} .5 \mathrm{H}_{2} \mathrm{O}, 2.0 \mathrm{~g} ; \mathrm{NaI}, 0.08 \mathrm{~g} ; \mathrm{MnSO}_{4} . \mathrm{H}_{2} \mathrm{O}, 3.0 \mathrm{~g}$; $\mathrm{Na}_{2} \mathrm{MoO}_{4} \cdot 2 \mathrm{H}_{2} \mathrm{O}, 0.2$ g; boric acid, 0.02 g; $\mathrm{CoCl}_{2} \cdot 6 \mathrm{H}_{2} \mathrm{O}$, 0.5 g; $\mathrm{ZnCl}_{2}, 7.0$ g; $\mathrm{FeSO}_{4} .7 \mathrm{H}_{2} \mathrm{O}, 22.0$ g; $\mathrm{CaSO}_{4} .2 \mathrm{H}_{2} \mathrm{O}$, $0.5 \mathrm{~g}$ and $\mathrm{H}_{2} \mathrm{SO}_{4}, 1 \mathrm{~mL}$. As required, glucose, magnesium, trace salts, thiamine and ampicillin were aseptically added as concentrated stock solutions to the media after sterilisation.

\section{Seed cultures}

Primary seed cultures were prepared from single colonies taken from a fresh transformation plate, and grown in $10 \mathrm{~mL}$ of $2 \mathrm{xYT}$ (in a $30 \mathrm{~mL}$ bottle) containing $10 \mathrm{~g} / \mathrm{L}$ glucose and $200 \mu \mathrm{g} / \mathrm{mL}$ ampicillin. The culture was incubated at $37^{\circ} \mathrm{C}$ shaking at $200 \mathrm{rpm}$ for $24 \mathrm{~h}$. A volume $(0.5 \mathrm{~mL})$ of the primary seed culture was used to inoculate $500 \mathrm{~mL}$ of $2 \mathrm{xYT}$ (in a $2 \mathrm{~L}$ Erlenmeyer flask) containing $10 \mathrm{~g} / \mathrm{L}$ glucose and $200 \mu \mathrm{g} / \mathrm{mL}$ ampicillin. This secondary seed culture was incubated at $37^{\circ} \mathrm{C}$ shaking at $200 \mathrm{rpm}$ for $16 \mathrm{~h}$.

\section{Protein expression in shake flasks}

Cultures were grown in $2 \mathrm{~L}$ Erlenmeyer flasks containing $500 \mathrm{~mL}$ of either $2 \mathrm{xYT}$ or DM media and incubated at $37^{\circ} \mathrm{C}$ for $24 \mathrm{~h}$. The cultures were then cooled to $25^{\circ} \mathrm{C}$ and protein expression induced by addition of $0.5 \mathrm{mM}$ isopropyl beta-D-thiogalactopyranoside (IPTG). The cultures were then incubated at $25^{\circ} \mathrm{C}$ for $10 \mathrm{~h}$ and for a further $14 \mathrm{~h}$ at $15^{\circ} \mathrm{C}$. Samples were taken during the course of the incubation and the cells pelleted by centrifugation followed by disruption using Bugbuster ${ }^{\mathrm{TM}}$ (Merck) and quantification by SDS-PAGE (as described below).

\section{Protein expression in $\mathbf{2 L}$ stirred tanks}

Recombinant bacterial collagens were produced in $2 \mathrm{~L}$ stirred tank bioreactors connected to a Biostat B (Sartorius Stedim Germany) control system. The initial volume of medium in the fermenter was $1.6 \mathrm{~L}$ and glucose as used as the carbon source. A volume of the secondary seed culture was added to the bioreactor to attain an initial optical density (measured at $600 \mathrm{~nm}$ ) of 0.25 . Foaming was controlled via the automatic addition of $10 \%$ (v/v) polypropylene glycol 2025; $3 \mathrm{~mL}$ of the antifoam solution was added prior to inoculation. The $\mathrm{pH}$ setpoint was 7.0, controlled by automatic addition of either $10 \%$ (v/v) $\mathrm{H}_{3} \mathrm{PO}_{4}$ or $10 \%(\mathrm{v} / \mathrm{v}) \mathrm{NH}_{3}$ solutions. The dissolved oxygen setpoint was $20 \%$ of saturation and a two-step 
cascade control was used maintain the dissolved oxygen above the specified setpoint. The agitator speed ranged from $500 \mathrm{rpm}$ to $1200 \mathrm{rpm}$ and airflow (supplemented with $5 \%$ pure $\mathrm{O}_{2}$ ) ranged from $0.3 \mathrm{~L} \mathrm{~min}^{-1}$ to $1.5 \mathrm{~L}$ $\mathrm{min}^{-1}$. For the high cell density fed-batch processes, the feed solution was comprised of $400 \mathrm{~mL}$ of $660 \mathrm{~g} / \mathrm{L}$ glucose solution to which $40 \mathrm{~mL}$ of $1 \mathrm{M} \mathrm{MgSO}_{4} 7 \mathrm{H}_{2} \mathrm{O}$ added. The feed flow rate was $15 \mathrm{~mL} \mathrm{~h}^{-1}$ and the feed was initiated $8.5 \mathrm{~h}$ after inoculation. Incubation times and temperatures for individual experiments are given in Table 1. The culture was cooled (over a 20 minute period) to the required temperature $24 \mathrm{~h}$ after inoculation to activate the cold shock component of the vector and protein expression induced by addition of $1 \mathrm{mM}$ (final concentration in the culture) IPTG.

\section{Preparation of protein standards}

Recombinant VCL and VCLH protein standards were extracted from wet cell paste by sonication in $40 \mathrm{mM}$ sodium phosphate buffer, pH8.0, $1 \mathrm{mM}$ phenylmethanesulfonyl fluoride, using $20 \mathrm{ml}$ buffer per gram of cell paste. After centrifugation, clarified supernatant was taken to $20 \mathrm{mM}$ sodium phosphate $300 \mathrm{mM} \mathrm{NaCl}$ and $30 \mathrm{mM}$ imidazole buffer, pH8.5, and absorbed onto a $\mathrm{Ni}$ charged HyperCel-Sepharose metal ion affinity resin (Pall Life Sciences). Elution was by the same buffer, but containing $500 \mathrm{mM}$ imidazole. Eluted fractions containing recombinant protein were pooled, concentrated and exchanged into $20 \mathrm{mM}$ sodium phosphate buffer, pH8.0, using a $10 \mathrm{kDa}$ cross-flow filtration membrane (Pall Life Sciences), followed by further purification in the same buffer on a Sephacryl S200 26/60 column (GE Healthcare). After additional treatment of purified VCL and VCLH with trypsin [19], SDS-PAGE [29] as described for Sample Analysis, was used to show that the triple helix remained intact.

\section{Sample analyses}

Samples were taken from the cultures throughout each process. Cell mass was determined by measuring the optical density of diluted samples at $600 \mathrm{~nm}\left(\mathrm{OD}_{600 \mathrm{~nm}}\right)$. VCL or VCLH were quantified in small sub-samples and to correct for changes in cell numbers, the formula 200/ $\mathrm{OD}_{600 \mathrm{~nm}}$ was used to determine the volume of culture required for SDS PAGE analysis. The aliquot was centrifuged and the cell pellet lysed by addition of $40 \mu \mathrm{L}$ of Bugbuster $^{\mathrm{TM}}$ (Merck) and incubated for $1 \mathrm{~h}$. After the incubation, $10 \mu \mathrm{L} 5 \mathrm{x}$ sample buffer containing $5 \%$ (v/v) 2mercaptoethanol was added to the lysate and the mixture heated at $95^{\circ} \mathrm{C}$ for $1 \mathrm{~min}$ prior to electrophoresis. SDS PAGE was completed as described by [29] using NuPAGE (Invitrogen) 4-12\% Bis-Tris gels with MES running gel buffer, at $180 \mathrm{~V}$ for $60 \mathrm{~min}$, followed by staining with Coomassie Blue R-250. After destaining, the band corresponding to VCL or VCLH bands were quantified by densitometric analysis using Multi Gauge V3.0 FujiFilm software and compared to known standard loadings of purified VCL protein.

\section{Competing interests}

All the authors declare that they have no competing interests.

\section{Authors' contributions}

YYP carried out construct production, shaker flask production, protein standard purification, yield quantitation and assisted in drafting the manuscript, LH carried out fermentation studies and VS carried out construct production and shaker flask production. JAW supervised the construct production and reviewed and revised the manuscript, GJD supervised design and implementation of the fermentation studies and reviewed and revised the manuscript. JAMR supervised the project and drafted the manuscript. All authors read and approved the final manuscript.

\section{Acknowledgment}

This work was supported in part through NIH grant \#EB011620.

Received: 1 September 2012 Accepted: 29 October 2012

Published: 5 November 2012

\section{References}

1. Mathews MB: Connective tissue: macromolecular structure and evolution. Berlin: Springer-Verlag; 1975.

2. Ricard-Blum S: The collagen family. Cold Spring Harb Perspect Biol 2011, 3:a004978.

3. Brodsky B, Ramshaw JAM: The collagen triple-helix structure. Matrix Biol 1997, 15:545-554

4. Ramshaw JAM, Shah NK, Brodsky B: Gly-X-Y tripeptide frequencies in collagen: a context for host-guest triple-helical peptides. J Struct Biol 1998, 122:86-91.

5. Persikov AV, Ramshaw JAM, Brodsky B: Prediction of collagen stability from amino acid sequence. J Biol Chem 2005, 280:19343-19349.

6. Ramshaw JAM, Werkmeister JA, Glattauer V: Collagen-based biomaterials. Biotechnol Genet Eng Rev 1996, 13:335-382.

7. Ramshaw JAM, Peng YY, Glattauer V, Werkmeister JA: Collagens as biomaterials. J Mater Sci Mater Med 2009, 20(Suppl 1):S3-S8.

8. Vaughan PR, Galanis M, Richards KM, Tebb TA, Ramshaw JAM, Werkmeister JA: Production of recombinant hydroxylated human type III collagen fragment in Saccharomyces cerevisiae. DNA Cell Bio/ 1998, 17:511-518.

9. Toman DP, Chisholm G, Mcmullin H, Giere LM, Olsen DR, Kovach RJ, Leigh SD, Fong BE, Chang R, Daniels GA, Berg RA, Hitzeman RA: Production of recombinant human type I procollagen trimers using a four-gene expression system in the yeast Saccharomyces cerevisiae. J Biol Chem 2000, 275:23303-23309.

10. de Bruin EC, de Wolf FA, Laane NC: Expression and secretion of human alpha1(I) procollagen fragment by Hansenula polymorpha as compared to Pichia pastoris. Enzyme Microb Technol 2000, 26:640-644.

11. Nokelainen M, Tu H, Vuorela A, Notbohm H, Kivirikko Kl, Myllyharju J: Highlevel production of human type I collagen in the yeast Pichia pastoris. Yeast 2001, 18:797-806.

12. Werkmeister JA, Ramshaw JAM: Recombinant protein scaffolds for tissue engineering. Biomed Mater 2012, 7:012002. doi:10.1088/1748-6041/7/1/ 012002.

13. Buechter DD, Paolella DN, Leslie BS, Brown MS, Mehos KA, Gruskin EA: Cotranslational incorporation of trans-4-hydroxyproline into recombinant proteins in bacteria. J Biol Chem 2003, 278:645-650.

14. Pinkas DM, Ding S, Raines RT, Barron AE: Tunable, post-translational hydroxylation of collagen Domains in Escherichia coli. ACS Chem Biol 2011, 6:320-324.

15. Xu Y, Keene DR, Bujnicki JM, Höök M, Lukomski S: Streptococcal Scl1 and Scl2 proteins form collagen-like triple helices. J Biol Chem 2002, 277:27312-27318.

16. Rasmussen M, Jacobsson M, Björck L: Genome-based identification and analysis of collagen-related structural motifs in bacterial and viral proteins. J Biol Chem 2003, 278:32313-32316. 
17. Xu C, Yu Z, Inouye M, Brodsky B, Mirochnitchenko O: Expanding the family of collagen proteins: recombinant bacterial collagens of varying composition form triple-helices of similar stability. Biomacromolecules 2010, 11:348-356

18. Mohs A, Silva T, Yoshida T, Amin R, Lukomski S, Inouye M, Brodsky B: Mechanism of stabilization of a bacterial collagen triple helix in the absence of hydroxyproline. J Biol Chem 2007, 282:29757-29765.

19. Yoshizumi A, Yu Z, Silva T, Thiagarajan G, Ramshaw JAM, Inouye M, Brodsky B: Self-association of streptococcus pyogenes collagen-like constructs into higher order structures. Protein Sci 2009, 18:1241-1251.

20. Sweeney SM, Orgel JP, Fertala A, McAuliffe JD, Turner KR, Di Lullo GA, Chen S, Antipova O, Perumal S, Ala-Kokko L, Forlino A, Cabral WA, Barnes AM, Marini JC, San Antonio JD: Candidate cell and matrix interaction domains on the collagen fibril, the predominant protein of vertebrates. J Biol Chem 2008, 283:21187-21197.

21. Knight CG, Morton LF, Peachey AR, Tuckwell DS, Farndale RW, Barnes MJ The collagen-binding A-domains of integrins $a(1) \beta(1)$ and $a(2) \beta(1)$ recognize the same specific amino acid sequence, GFOGER, in native (triple-helical) collagens. J Biol Chem 2000, 275:35-40.

22. Cosgriff-Hernandez E, Hahn MS, Russell B, Wilems T, Munoz-Pinto D, Browning MB, Rivera J, Höök M: Bioactive hydrogels based on designer collagens. Acta Biomater 2010, 6:3969-3977.

23. Deprez P, Doss-Pepe E, Brodsky B, Inestrosa NC: Interaction of the collagen-like tail of asymmetric acetylcholinesterase with heparin depends on triple-helical conformation, sequence and stability. Biochem J 2000, 350:283-290.

24. Doss-Pepe E, Deprez P, Silva T, Inestrosa NC, Kirkpatrick A, Ramshaw JAM, Brodsky B: Stepwise construction of triple-helical heparin binding sites using peptide models. Biochim Biophys Acta 2004, 1698:187-195.

25. Peng YY, Yoshizumi A, Danon SJ, Glattauer V, Prokopenko O,

Mirochnitchenko O, Yu Z, Inouye M, Werkmeister JA, Brodsky B, Ramshaw JAM: A Streptococcus pyogenes derived collagen-like protein as a non-cytotoxic and non-immunogenic cross-linkable biomaterial. Biomaterials 2010, 31:2755-2761.

26. Qing G, Ma LC, Khorchid A, Swapna GV, Mal TK, Takayama MM, Xia B, Phadtare S, Ke H, Acton T, Montelione GT, Ikura M, Inouye M: Cold-shock induced high-yield protein production in Escherichia coli. Nature Biotechnol 2004, 22:877-882.

27. Symersky J, Patti JM, Carson M, House-Pompeo K, Teale M, Moore D, Jin L, Schneider A, DeLucas $L$, Höök M, Narayana SV: Structure of the collagenbinding domain from a Staphylococcus aureus adhesin. Nature Struct Biol 1997, 4:833-838

28. Adrio JL, Demain AL: Recombinant organisms for production of industrial products. Bioeng Bugs 2010, 1:116-131.

29. Laemmli UK: Cleavage of structural proteins during the assembly of the head of bacteriophage T4. Nature 1970, 227:680-685.

doi:10.1186/1475-2859-11-146

Cite this article as: Peng et al:: Towards scalable production of a collagen-like protein from Streptococcus pyogenes for biomedical applications. Microbial Cell Factories 2012 11:146.

\section{Submit your next manuscript to BioMed Central and take full advantage of:}

- Convenient online submission

- Thorough peer review

- No space constraints or color figure charges

- Immediate publication on acceptance

- Inclusion in PubMed, CAS, Scopus and Google Scholar

- Research which is freely available for redistribution

Submit your manuscript at www.biomedcentral.com/submit
C BioMed Central 